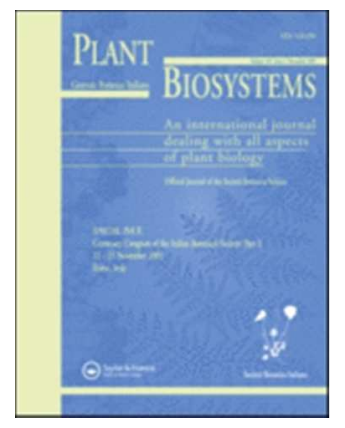

\title{
Inhibitory effect of Ocotea quixos (Lam.) Kosterm. and Piper aduncum L. essential oils from Ecuador on West Nile virus infection.
}

\begin{tabular}{|r|l|}
\hline Journal: & Plant Biosystems \\
\hline Manuscript ID & TPLB-2018-0017.R1 \\
\hline Danuscript Type: & Original Article \\
\hline Complete List of Authors: & $\begin{array}{l}\text { Radice, Matteo; Universidad Estatal Amazonica } \\
\text { Pietrantoni, Agostina; Istituto Superiore di Sanita } \\
\text { Guerrini, Alessandra; Universita degli Studi di Ferrara } \\
\text { Tacchini, Massimo; Universita degli Studi di Ferrara Dipartimento di } \\
\text { Scienze della Vita e Biotecnologie } \\
\text { Sacchetti, Gianni; Universita degli Studi di Ferrara } \\
\text { Chiurato, Matteo; Universita degli Studi di Ferrara } \\
\text { Venturi, Giulietta; Istituto Superiore di Sanita } \\
\text { Fortuna, Claudia; Istituto Superiore di Sanita, }\end{array}$ \\
\hline Keywords: & $\begin{array}{l}<\text { i>OCotea quixos</i>, <i>Piper aduncum</i>, essential oil, West Nile } \\
\text { virus, antiviral activity, Ecuadorian Amazon Region }\end{array}$ \\
\hline \multicolumn{2}{|l}{} \\
\hline
\end{tabular}


1 Inhibitory effect of Ocotea quixos (Lam.) Kosterm. and Piper aduncum

2 L. essential oils from Ecuador on West Nile virus infection.

3 Matteo Radice ${ }^{1}$, Agostina Pietrantoni ${ }^{2}$, Alessandra Guerrini ${ }^{3}$, Massimo

4 Tacchini $^{3}$, Gianni Sacchetti ${ }^{3}$, Matteo Chiurato $^{3}$, Giulietta Venturi ${ }^{4}$, Claudia

5 Fortuna $^{4 *}$

$6 \quad{ }^{1}$ Universidad Estatal Amazónica, Puyo, Ecuador

$7 \quad{ }^{2}$ National Center for Innovative Technologies in Public Health, Istituto Superiore di 8 Sanità, Rome, Italy

$9{ }^{3}$ Department of Life Sciences and Biotechnology (SVeB), University of Ferrara, 10 Malborghetto di Boara, Ferrara, Italy

$11{ }^{4}$ Department of Infectious Diseases, Istituto Superiore di Sanità, Rome, Italy

12

$13 *$ Corresponding author: Dr. Claudia Fortuna

14 E-mail address: claudia.fortuna@,iss.it

16 Matteo Radice, Universidad Estatal Amazónica, Km 2 1/2 Via Puyo-Tena, Puyo,

17 Ecuador, mradice@uea.edu.ec, 00593 032-888-118 / 032-889-118

18 Agostina Pietrantoni, National Center for Innovative Technologies in Public Health, 19 Istituto Superiore di Sanità, Viale Regina Elena 299, 00161 Rome, Italy, 20 agostina.pietrantoni@,iss.it, +390649902092

21

22

Alessandra Guerrini, Department of Life Sciences and Biotechnology (SVeB), University of Ferrara, P.le Chiappini, 344123 Malborghetto di Boara, Ferrara, Italy,

24 alessandra.guerrini@,unife.it, +390532293774+390532293781

25

Massimo Tacchini, Department of Life Sciences and Biotechnology (SVeB), University 27 of Ferrara, P.le Chiappini, 344123 Malborghetto di Boara, Ferrara, Italy, massimo.tacchini@unife.it, +390532293774+390532293781

29

30 Gianni Sacchetti, Department of Life Sciences and Biotechnology (SVeB), University

31 of Ferrara, P.le Chiappini, 344123 Malborghetto di Boara, Ferrara, Italy, scg@unife.it, $32+390532293774+390532293781$ 
33 Matteo Chiurato, Department of Life Sciences and Biotechnology (SVeB), University

34 of Ferrara, P.le Chiappini, 344123 Malborghetto di Boara, Ferrara, Italy,

35 matteo.chiurato@gmail.com,+390532293774+390532293781

36 Giulietta Venturi, Department of Infectious Diseases, Istituto Superiore di Sanità, Viale

37 Regina Elena 299, 00161 Rome, Italy, giulietta.venturi@iss.it,+390649902663

38 Claudia Fortuna, Department of Infectious Diseases, Istituto Superiore di Sanità, Viale

39 Regina Elena 299, 00161 Rome, Italy, claudia.fortuna@iss.it, +390649902663

40

\section{Abstract}

West Nile virus (WNV) is a mosquito-borne flavivirus responsible of neuroinvasive manifestations. Natural products are well-known for their biological activities and pharmaceutical application. In this study the inhibitory effects of essential oils (EOs) of Ocotea quixos (Lam.) Kosterm. and Piper aduncum L. on WNV replication were investigated.

WNV was incubated with EOs before adsorption on Vero cells, viral replication was carried out in the absence or presence of EO. Cells were exposed to EO before the adsorption of untreated-virus. GC-MS and GCFID were used for chemical characterization of EOs.

Cell protection from infection was observed for both EOs. P. aduncum EO was characterized by dillapiole as main compound (48.21\%) and O. quixos EO by 1,8-cineole (39.15\%). such as the study of molecular and cellular mechanisms of action and in vivo evaluation for the development of a compound against WNV. Further investigations, such as the study of molecular and cellular mechanisms of action and in vivo evaluation, should be performed on these essential oils to derive new potential drugs against WNV. 
Keywords: Ocotea quixos, Piper aduncum, essential oil, West Nile virus, antiviral activity, Ecuadorian Amazon Region.

\section{Introduction}

West Nile virus (WNV) is a mosquito-borne flavivirus, family Flaviviridae, widely distributed throughout Africa, the Middle East, Asia, Southern Europe, Australia and the Americas. The virus was originally isolated from Uganda in 1937. WNV caused epidemic outbreaks in Asia, Europe and Australia and, in the 1999, it was introduced into the United States where it became endemic (Saxena et al. 2017). While birds serve as amplifier hosts, mosquitoes of the Culex genus function as vectors. Humans and horses are dead-end hosts (David and Abraham 2016). WNV causes asymptomatic infections in $80 \%$ of cases, while $19 \%$ of patients develop flu-like illnesses. In less than $1 \%$ of the symptomatic individuals, virus entry into the central nervous system (CNS) results in neuroinvasive manifestations, such as meningitis, encephalitis, poliomyelitis, and death (Gubler 2007). Despite the important impact of WNV infection-associated diseases on human health, there are currently no available human vaccines or specific antiviral therapies for this disease. To date, only a West Nile vaccine is available for horses. Natural products are widely used all over the world as treatment for many diseases and deepene 1 vestigations are justified from several studies (Newman and Cragg 2007; Bhalla et al. 2013; Atanasov et al. 2015). A recent study demonstrated the antiviral potential of different polyphenols present in plants and natural products, such as wine and tea, against WNV, by affecting the attachment and entry steps of the virus life-cycle (Vázquez-Calvo et al. 2017). Further studies on the antiviral potential of 
natural compounds against WNV are not reported to date. Moreover, Ecuador belongs

90 to a selected group of 17 countries defined "Megadiverse" due to its impressive

91 biological diversity (Mittermeier et al. 1999;; Sierra et al. 2002), which is an important

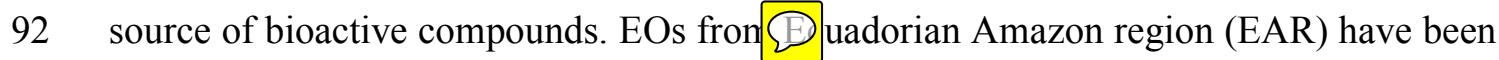

93 investigated in the last decades in order to deepe 0 ir biological activities (Bruni et al.

94 2004; Tognolini et al. 2006; Sacchetti et al. 2006; Scalvenzi et al. 2007; Guerrini et al. 95 2014).

96 To our knowledge, studies evaluating antiviral effec@ o. quixos (Lam.) Kosterm.

97 (Lauraceae) and P. aduncum L. (Piperaceae) EOs against WNV have not been reported.

98 O. quixos (Lam.) Kosterm belongs to the Lauraceae family. It is traditionally used as

99 ingredient for infusions and beverages or as a flavoring for foods (Naranjo 1981;

100 Friedman et al. 1993). Although few studies have been carried out on the biological

101 properties of $O$. quixos, in vivo and in vitro investigations on this plant highlighted

102 significant anti-inflammatory activity of its EO (Ballabeni et al. 2009).

103 P. aduncum, from Piperaceae family, is well-known in folk medicine for the 104 antimicrobial and insecticide activities and for the treatment of dysentery and wound 105 healing (Durant-Archibold et al. 2018).

106 Many studies have been performed on $P$. aduncum demonstrating $(\mathbb{D}$ icacy o\& as 107 insect repellent (Mamood et al. 2017) and (1) thanolic extract as antiviral plant-derived 108 product (Lohézic-Le Dévéhat et al. 2002). Moreover the importance of the $P$. aduncum 109 EO has been demonstrated also against $P$. falciparum indicating that this EO could be a 110 promising antimalarial agent (Monzote et al. 2017). In an effort to identify antiviral 111 therapies effective against WNV, in this study potential antiviral effed quixos and $P$. 112 aduncum EOs were tested in vitro.

\section{Methods}


114 Material and Methods

\section{Plant material}

116 Fresh leaves of $O$. quixos (Canela amazónica) and P. aduncum (Matiko) plants were

117 collected from a wild population in the Amazonian region of Pastaza (Ecuador) in June

118 2016. Species authentication were certified by Dr. David Neill and voucher specimens

119 from each plant were deposited at the Herbarium ECUAMZ of the Amazonian State

120 University (UEA) in Ecuador (voucher specimen: Neill 18070B, Scalvenzi 18070C).

\section{Isolation of EOs}

123 The EOs were obtained by hydrodistillation in a stainless steel distiller equipped with a

124 Clevenger apparatus, performing three distinct distillations for $4 \mathrm{~h}$. All samples for each

125 EO were gathered, dried over anhydrous sodium sulphate and stored in sealed amber 126 vials at $4^{\circ} \mathrm{C}$.

\section{Gas-chromatographic analysis of EOs}

129 The compound identification was realized by GC-MS analysis and the quantification of 130 individual components was performed by GC-FID, calculating the relative peak average

131 area of three separated injections. The instrument used for quantitative determination 132 was a ThermoQuest GC-Trace gas-chromatograph equipped with a FID detector and a 133 Varian FactorFour VF-5ms poly-5\% phenyl-95\%-dimethylsiloxane column (i.d., 0.25 $134 \mathrm{~mm}$; length, $30 \mathrm{~m}$; film thickness, $0.15 \mu \mathrm{m})$. Operating conditions were as follows: 135 injector temperature $300^{\circ} \mathrm{C}$, FID temperature $300^{\circ} \mathrm{C}$, carrier (Helium) flow rate 1 $136 \mathrm{~mL} / \mathrm{min}$ and split ratio $1: 50$. The initial oven temperature was $55^{\circ} \mathrm{C}$ and then raised to 
$137100^{\circ} \mathrm{C}$ at a rate of $1^{\circ} \mathrm{C} / \mathrm{min}$, then raised to $250^{\circ} \mathrm{C}$ at a rate of $5^{\circ} \mathrm{C} / \mathrm{min}$ and then kept

138 constant at $250^{\circ} \mathrm{C}$ for $15 \mathrm{~min}$. One microliter for each replicate was dissolved in $\mathrm{CH}_{2} \mathrm{Cl}_{2}$

139 (Sigma-Aldrich) and injected. The EOs percentage composition was computed by the 140 normalization method from the GC peak areas, without using correction factors. The

141 compound identification of EOs were performed by a Varian GC-3800 gas

142 chromatograph equipped with a Varian MS-4000 mass spectrometer using electron 143 impact and hooked to NIST library. The conditions were the same described for GC 144 analysis and also the same column was used. The mass spectrometry conditions were as 145 follows: ionization voltage, $70 \mathrm{eV}$; emission current, $10 \mu \mathrm{Amp}$; scan rate, $1 \mathrm{scan} / \mathrm{s}$; mass 146 range, $29-400 \mathrm{Da}$; trap temperature, $150^{\circ} \mathrm{C}$, transfer line temperature, $300^{\circ} \mathrm{C}$. The EO 147 compounds were characterized by comparing their linear retention indices and the MS 148 fragmentation pattern with those of other known EOs, with pure compounds and by 149 matching the MS fragmentations patterns and linear retention indices with the above

150 mentioned mass spectra libraries and with those in the literature (Adams 2007). The 151 linear retention index of each component was determined adding a $\mathrm{C}_{8}-\mathrm{C}_{32}$ n-alkanes 152 (Sigma-Aldrich) to the EO before injecting in the GC-MS equipment and analyzed 153 under the same conditions reported above (Guerrini et al. 2014)[14].

\section{Preparation of mother solution for biological assays}

156 An aliquot of dimethylsulfoxide (DMSO; Sigma-Aldrich) was added to the stock 157 solution of each EO in order to obtain a $84 \mathrm{mg} / \mathrm{mL}$ concentration range. Serial dilutions 158 of the DMSO/EO solution were made with virus dilution buffer for the infection and 159 with MEM maintenance medium for maintaining. 


\section{Cell culture and virus}

162 African green monkey kidney (Vero) cells were grown at $37^{\circ} \mathrm{C}$ in a humidified 163 atmosphere, with 5\% $\mathrm{CO}_{2}$ in Dulbecco's modified Eagle's medium (DMEM; Lonza, 164 Milan, Italy) supplemented with 10\% inactivated fetal calf serum (FCS, Flow 165 Laboratories, Irvine, UK.), $2 \mathrm{mM}$ glutamine, 2\% non-essential amino acids (Gibco, 166 Paisley, UK), penicillin $(100 \mathrm{IU} / \mathrm{mL})$, and streptomycin $(100 \mu \mathrm{g} / \mathrm{mL})$. WNV strain,

167 lineage 1, isolated from a patient during the WNV outbrea @urred in $\$$ dinia Region 168 in 2011 (Magurano et al. 2012) [15] was used for the study. For virus production 169 monolayers of Vero cells in $75-\mathrm{cm}^{2}$ tissue culture flasks were infected with WNV. After 1705 days at $37^{\circ} \mathrm{C}$, infected cells were harvested with freeze-and-thaw cycle, and cellular 171 debris was removed with low-speed centrifugation, and virus titer was measured by 172 standard plaque assay. The virus was stored at $-80^{\circ} \mathrm{C}$ until used.

173

174 Plaque assay

175 WNV titer was determined by plaque assays in Vero cells growing in 24-well plates.

176 Briefly, serial tenfold dilutions of the viral suspension were added $(0.1 \mathrm{~mL} / \mathrm{well})$ in 177 duplicate. After infection, the cells were incubated for $1 \mathrm{~h}$ at $37^{\circ} \mathrm{C}$. Subsequently, 178 Tragacanth gum powder (SIGMA cat. G1128-100G) supplemented 1:1 with DMEM 179 medium with 5\% inactivated FBS, $2 \mathrm{mM}$ glutamine, 2\% non-essential amino acids, 180 penicillin $(100 \mathrm{IU} / \mathrm{mL})$, and streptomycin $(100 \mu \mathrm{g} / \mathrm{mL})$ was added, and the plate was 181 incubated for 5 days at $37^{\circ} \mathrm{C}$. The viral plaques were visualized by $1 \%$ crystal violet 182 solution (Fortuna et al. 2015). The titer was estimated by counting the number of 
183 plaques observed in each well and expressed as plaque-formation unit per milliliter

184 (p.f.u. $/ \mathrm{mL})\left(\right.$ viral titer: $6,93 \times 10^{6}$ p.f.u. $\left./ \mathrm{mL}\right)$.

185

186 Cytotoxicity assay

187 A cytotoxicity test was performed for all EOs. Each EO was diluted 1:10 in DMSO and 188 subsequent several dilutions were made in MEM medium. Vero cell monolayers were 189 put in contact with the mixture of MEM medium plus oil and maintained at $37^{\circ} \mathrm{C}$ with $1905 \% \mathrm{CO} 2$. The cells were monitored daily to check the EO toxicity. After $24 \mathrm{~h}$, the

191 following parameters were evaluated: cell morphology and viability (determined by 192 neutral re $\$$ aining) were examined by light microscopy and cell proliferation was 193 evaluated quantitatively by microscopic counts after dispersion into individual cells 194 with trypsin. EO dilutions that did not affect any of these parameters were considered as 195 non-cytotoxic concentrations and utilized for antiviral assays. For neutral re aining 196 the $50 \%$ cytotoxic concentration $\left(\mathrm{CC}_{50}\right)$ was defined as the concentration that reduces

197 the optical density (OD) of treated cells to 50\% with respec untreated cells 198 (Pietrantoni et al. 2015).

\section{Dose-Response Assay}

201 The antiviral activity of $O$. quixos and $P$. aduncum EOs was assayed by neutral re 202 assay. Briefly, in 96-well culture plate, monolayer cultures of Vero cells were incubated 203 with different concentrations of $O$. quixos and $P$. aduncum starting from $2.6 \mu \mathrm{g} / \mathrm{mL}$ 204 during the virus attachment step $\left(1 \mathrm{~h} 4^{\circ} \mathrm{C}\right)$. As viral inoculum was utilized WNV at a 205 multiplicity of infection (m.o.i.) of 0.1 p.f.u./cell. After adsorption, Vero cells were 
206 rinsed thoroughly and incubated with the same concentrations of EO. The cells were

207 maintained at $37^{\circ} \mathrm{C}$ in $5 \% \mathrm{CO}_{2}$. The cytopathic effect (CPE) induced by WNV was

208 measured 72 hours after infection by the neutral re prake assay. Briefly, treated and 209 untreated cells were stained for $3 \mathrm{~h}$ at $37^{\circ} \mathrm{C}$ with neutral re $0 \mathrm{mg} / \mathrm{mL}$ ), thereafter

210 cells were washed with Phosphate Buffered Saline (PBS) and fixed with 4\%

211 formaldehyde, $10 \% \mathrm{CaCl}_{2}$. The uptaken dye was extracted by $1 \%$ acetic acid in $50 \%$

212 ethanol and the optical density was measured at $540 \mathrm{~nm}$ in a spectrophotometer

213 (Pietrantoni et al. 2015). Results were expressed as percentage of cell viability with

214 untreated infected control cultures. The concentration that reduced the absorbance of

215 infected cells to $50 \%$ when compared to cell and virus controls was considered the

216 effective concentration $\left(\mathrm{EC}_{50}\right)$. The $\mathrm{EC}_{50}$ was calculated according to the following

217 equation: $[(\mathrm{A}-\mathrm{B}) /(\mathrm{C}-\mathrm{B}) \mathrm{x} 100]$, where $\mathrm{A}$ is the control sample absorbance, $\mathrm{B}$ is the

218 cell control absorbance, and $\mathrm{C}$ is the virus control absorbance. The selectivity index (SI)

219 was calculated using the $\mathrm{CC}_{50}$ and $\mathrm{EC}_{50}$ data and applying the formula $\mathrm{SI}=\mathrm{CC}_{50} / \mathrm{EC}_{50}$.

221 Antiviral activity

222 The antiviral activity of the EOs was measured using the neutral re say as already 223 described. The antiviral assays were performed at $24 \mathrm{~h}$ after seeding, using confluent 224 Vero cell monolayers cultured in 96-well plates. EOs and components were always used 225 at the non-cytotoxic concentration as follows $(33.6,16.8,2.1,1 \mu \mathrm{g} / \mathrm{mL})$. Cells without 226 the EO were used as a control. The EOs were included infferent time point it 227 follows:

228 i. To evaluate the presence of virucidal activity, direct inactivation of WNV by the 229 extracts was tested. Viral inoculum was mixed with varying concentrations of the EO 
230 incubated at $37^{\circ} \mathrm{C}$ in $5 \% \mathrm{CO}_{2}$ for $1 \mathrm{~h}$. After that, viral inoculum was used to infect

231 monolayer cultures of Vero cells, at a m.o.i. of 0.1 p.f.u./cell. After incubation at $37^{\circ} \mathrm{C}$

232 in $5 \% \mathrm{CO}_{2}$ for $1 \mathrm{~h}$, the cells were washed and DMEM maintenance medium was added 233 and the cells were maintained at $37^{\circ} \mathrm{C}$ in $5 \% \mathrm{CO}_{2}$.

234 ii. Cell monolayers were pre-treated $1 \mathrm{~h}$ at $37^{\circ} \mathrm{C}$ with $\mathrm{EO}$ prior to inoculation with virus 235 by adding the EO at varying concentrations. After pre-treatment, the EO was removed 236 and cells were infected with virus at a m.o.i. of 0.1 p.f.u./cell and incubated at $37^{\circ} \mathrm{C}$ in $2375 \% \mathrm{CO}_{2}$ for $1 \mathrm{~h}$. Then MEM maintenance medium was added and the cells were 238 maintained at $37^{\circ} \mathrm{C}$ in $5 \% \mathrm{CO}_{2}$.

239 iii. Experiments were also performed to determine the viral inhibitory effect of the 240 selected EOs during the adsorption step. Vero cells grown in 96-well plates were 241 infected in triplicate with 0.1 p.f.u./cell of virus and EO at concentration described 242 above.

243 For all the treatments the neutr $\mathrm{D}$ ed assay procedure was performed $72 \mathrm{~h}$ later, 244 according to the protocol described in cell viability assay (Pietrantoni et al. 2015).

246 Statistical analysis

247 The experiments were performed in triplicate. Relative standard deviations and 248 statistical significance (Student's t test; $\mathrm{p} \leq 0.05$ ) were calculated using software 249 STATISTICA 6 6 tatSoft Italia srl).

251 Results

252 Chemical composition of EOs 
1

2

3

4

5

6

7

8

10
253 The yield of distillation for $\theta$. quixes $\mathrm{E} O$ was $0.13 \pm 0.01 \%(\mathrm{w} / \mathrm{v})$. The main component

254 (Table 1) was represented by 1,8-ineole (39.15\%), followed in less amount by a255 terpineol (7.65\%), sabinene (6.46\%), a-pinene (6.27\%), p-cymene (6.12\%), Eearyophyllene $(4.73 \%)$, terpinen-4-ol (4.22\%). Monoterpenes represented the main fraction of EO. Methyl cinnnamate, a characteristic phenylpropanoid of floral calice EO (Bruni et al 2004), was a minor compound in EO obtained from leaves (1.53\%). For $P$. aduncum EO, the yield was $0.16 \pm 0.01 \%(\mathrm{w} / \mathrm{v})$. The phenylpropanoid dillapiole (48.21\%), trans-ocimene (7.53\%) and E-caryophyllene (4.80\%) were the main eompounds.

\section{Cytotoxicity of EOs}

A neutral red assay was used to determine the cytotoxicity effect of $\theta$. quixos and $P$. atn on Vero cells in which the half maximal cytotoxic concentration (CC50) value of each-compound was caleulated. Results illustrate a cyotoxic value of CC50- 163 $\mu \mathrm{g} / \mathrm{mL}$ for $P$. aduncum compared to $O$. quixes with $\mathrm{CC} 50=840 \mu \mathrm{g} / \mathrm{ml}$. Treated cells with vehicle control, 1\% DMSO did not show any cytotoxicity against Vero cells.

\section{Dose-Response-Assay}

In order to evaluate the effect of $O$. quixos and $P$. aduncum on viral replication, Vere eells were infected with WNV at 0.1 m.o.i. p.f.u./cell and exposed to various two-folds eoncentrations of EO starting from $2.6 \mu \mathrm{g} / \mathrm{ml}$ for $72 \mathrm{~h}$ post infection (p.i.).

Results are presented in Fig 1 as percentage of cell viability and represent the average of three independent experiments. As showed in the figure both EOs were able to inhibit 
276 viral replication but $O$. quixes was more effective at concentration of 268 and 134,4

$277 \mu \mathrm{g} / \mathrm{ml}$ respect $P$. aduncum that showed a viral inhibition similar for all concentration.

278 The $50 \%$ effective concentration (EC50) for 0. quixos was $372 \mu \mathrm{g} / \mathrm{ml}$ whit a selectivity

279 index (SI) of 2.2 as showed on (Table 2).

280

281 Antiviral activity of $\boldsymbol{\theta}$. quixes on WNV

282 In order to better investigate the inhibitory effects of $\theta$. quixos on WNV, EO was added 283 at different stages during viral infection. As showed on Fig $2(\mathrm{~A})$, pre-treatment of virus

284 with $O$. quixos showed relevant virucidal activity at concentrations of $33.6 \mu \mathrm{g} / \mathrm{ml}$ and $28516.8 \mu \mathrm{g} / \mathrm{ml}$. The EO was also effective at these concentrations when host cells were pre286 treated with drugs prior to infection, showing a percentage of cell vitality of $60 \%$ (Fig 2

287 (B)). Same results were obtained when $O$. quixes EO at concentration of $33.6 \mu \mathrm{g} / \mathrm{ml}$ and $28816.8 \mu \mathrm{g} / \mathrm{ml}$ was present during the adsorption step (Fig 2 (C)). We, therefore, observed 289 similar inhibition effect on viral replication in all three conditions studied, when the EO 290 was used at the concentrations of $33.6 \mu \mathrm{g} / \mathrm{ml}$ and $16.8 \mu \mathrm{g} / \mathrm{ml}$, with a percentage of cell 291 viability around $60 \%$. No relevant inhibition was observed when the WNV was pre292 treated with EO at the concentrations of $2.1 \mu \mathrm{g} / \mathrm{ml}$ and $1 \mu \mathrm{g} / \mathrm{ml}$, for all conditions used $293(\operatorname{Fig} 2(\mathrm{~A}, \mathrm{~B}, \mathrm{C}))$.

295 Antiviral activity of $\boldsymbol{P}$. aduncum on WNV

296 As showed on Fig 3 (A) antiviral activity of the $P$. aduncum was most pronounced 297 when viruses were treated before inoculation showing a percentage of cell viability of $29879 \%$ at the concentrations of $33.6 \mu \mathrm{g} / \mathrm{ml}, 88 \%$ at $16.8 \mu \mathrm{g} / \mathrm{ml}, 87 \%$ and $78 \%$ at 2.1 an 1 $299 \mu \mathrm{g} / \mathrm{ml}$, respectively. When cells were incubated with EO only $1 \mu \mathrm{g} / \mathrm{ml}$ showed a small 300 protection (68\% of cell viability) while no relevant antiviral activity was showed by the 
1

2

3

4

5

6

7

8

9

10

301 other concentrations (Fig 3(B)). When the EO was added during infection, the results

302 showed an antiviral activity at all the concentrations with a percentage of cell viability

303 of around $68 \%$ at $1 \mu \mathrm{g} / \mathrm{ml}$ (Fig 3 (C)).

304

\section{Discussion and conclusion}

306 Viral diseases are still a major problem for human health worldwide. Although natural

307 products have inherently high chemical diversity, plant based products or bioactive pure

308 compounds obtained from EOs may be a new source of antiviral drugs but a few

309 number of studies focus on this research field. So far, only a limited number of drugs

310 are effective against many of these viruses, which has prompted research into finding

311 new antiviral lead molecules (Li et al. 2013, Elizaquível et al. 2013, Tanu and Harper

312 2016, Schnitzler et al. 2007, Astani et al. 2010, Lohézic Le Dévéhat et al. 2002,

313 Ocazionez et al. 2010, Swamy et al. 2016). P. aduncum EO has been investigated by

314 several authors mainly focusing chemical characterization, antimicrobial, insecticidal,

315 larvicidal and anti-protozoic (Guerrini et al. 2009, Bernuci et al. 2016, Oliveira et al.

316 2013, Villamizar et al. 2017, Ling A et al. 2009, Monzote et al. 2017), but no data are

317 available regarding antiviral activity. Also $O$. quixes EO was characterized and tested

318 for its antimicrobial, antiplatelet and antithrombotic activity (Sacchetti et al. 2006,

319 Naranjo 1981, Rolli et al. 2014, Tognolini et al. 2006, Ballabeni et al. 2007); from our

320 knowledge no antiviral activities test were performed until now. The limited efficacy of

321 the current treatment of WNV infection enhances the need for novel therapies that

322 include substances with innovative viral targets and/or mechanisms of action. Our study

323 has been performed to analyse the potential capacity of $O$. quixos and $P$. aduncum EOs,

324 collected in the Ecuadorian Amazon, to reduce the WNV replication in infected cells. 
325 The chemical composition of leaf $O$. quixes EO, showing 1,8-cineole (39.15\%) as main

326 eomponent, cinnamate derivatives and E-caryophyllene among minor compounds, did

327 not reflect our previously results (Sacchetti el al. 2006), where E-caryophyllene,

328 einnamyl acetate and other derivatives were the characteristic molecules. The yield was

329 instead comparable with our previous results. However, it should be noted that the

330 variation of chemical composition for this EO has not yet been studied extensively. $P$.

331 aduncum EO showed an overlapping composition to our previously data (Guerrini et al.

332 2009), with small quantitative differences regarding minor compounds: furthermore,

333 germacrene $\mathrm{D}(3.05 \%)$ was not detected in the previous studies. $P$. aduncum EO have

334 been largely studied in the last two decades and the formation of two chemotypes by

335 different biosynthetic routes has been evidenced. In fact, according to our data, Maia et

336 al. (1998), Cicció and Ballestero (1997), Fazolin et al. (2007), De Almeida et al. (2009)

337 isolated EOs from leaves of $P$. aduncum in different localities of Amazonian region and

338 determined that dillapiole, formed by the shikimate pathway, was the main compound

339 with a variability from $31.5 \%$ to $97.3 \%$. The study of $P$. aduncum cultivation in

340 Western Amazonian region confirmed dillapiole as major component (Silva et al. 2014).

341 If the leaves were instead collected from species in Atlantic Forest, and Northeastern

342 and Southeastern Brazil, terpene compounds such as (E)-nerolidol and linalool were

343 detected as main components (De Almeida et al. 2009, De Oliveira et al. 2006,

344 Navickiene et al. 2006). The yield of dillapiole-chemotype EO in literature ranged from

$3450.35 \%$ to 4.0\% (Guerrini et al. 2009, Fazolin et al. 2007, De Almeida et al. 2009, Silva

346 et al. 2014, Rali et al. 2007), our results instead showed a lower level $(0.16 \%)$

347

348 EOs were tested for their cytotoxicity on Vero cells, prior to the determination of their

349 inhibitory effect against WNV. P. aduncum resulted relatively more toxic than $O$. 
1

2

3

4

5

6

7

8

350 quixes. The potential antiviral effect of different EOs was determined against WNV on

351 Vero cells in vitro and both EOs tested exhibited a reduction of infectivity at non-

352 eytotoxic concentration.

353 High antiviral activity was observed for selected EOs when WNV was incubated whit

354 this substances prior host cell infection (virucidal activities). WNV is an enveloped

355 virus and the results of our study highlighted that both $O$. quixos and $P$. aduncum show

356 virucidal activity.

357 Experiments aimed to assess the antiviral activity of EOs have been most frequently 358 conducted on viruses of the herpes group, enveloped viruses (Novak 2011). Schnitzler 359 et al. (2007) demonstrated a virucidal effect of peppermint oil, when herpes simplex

360 virus was mixed with the essential oil prior to inoculation. The application of tea tree

361 oil, the EO of Melaleuca alternifolia, for the treatment of recurrent herpes labialis has 362 been recently reported (Carson et al. 2001, Schuhmacher et al. 2003). Accordingly, a 363 virus lacking of envelope, like adenovirus, was not affected by eucalyptus EO (Cemelli 364 et al. 2008). Therefore our results suggest that $O$. quixos and $P$. aduncum could directly 365 inactivate WNV and might interfere with virion envelope structures or mask viral 366 structures which are necessary for adsorption or entry into host cells.

367 In this study, experiments were also performed to determine the viral inhibitory effect

368 treating the cells with EOs before adsorption. This different approach was important to

369 better investigate on mechanisms of antiviral action of the EOs. In our study, O. quixos

370 showed a protection of the cells from viral infection unlike $P$. aduncum. These findings

371 would suggest an ability of $O$. quixes to inhibit viral replication by interfering with the 372 virus binding to the cells. $P$. aduncum didn't result protective when added to the cells 373 before inoculum. In this case we might, in some ways, assume that the oil does not act 
374 by competing with the virus for binding to the cell, and that part of its activity relies on

375 direct inactivation of the viral particles after virus adsorption.

376 For 0 . quixes we observed a good and similar protection from WNV infection adding

377 the EO to the DMEM medium during the intracellular replication period, up to an EO

378 concentration of $16.8 \mu \mathrm{g} / \mathrm{ml}$. These results suggest that $O$. quixos could act directly on

379 WNV virus and might interfere with virion envelope structures or mask viral structures,

380 which are necessary for adsorption or entry into host cells. Thus different mechanisms

381 of antiviral activity of different EOs and compounds seem to be present.

382 All together, these results support the potential use of EOs in toto from medicinal plants

383 as agents for the treatment of viral infections. The effectiveness of the EOs from

384 Amazonia against the viruses tested was variable, but their virucidal properties against

385 these viruses suggest the application of this type of natural products as disinfectants or

386 topical medicaments.

387 Previous studies with EOs from eucalyptus, tea tree and thyme (Astani et al. 2010),

388 have shown the direct inactivating action of EOs and their components on virion

389 infectivity (HSV-1), with the exception of 1,8-cineole. In particular, $\alpha$-pinene, $\alpha$ -

390 terpineol, terpinen-4-ol and p-cymene, detected in considerable amount in 0 . quixos

391 EO, revealed a high antiviral activity and could be responsible for inactivation action.

392 However, in our research, further investigation is required to better elucidate the active

393 components and their mixture responsible of the inhibitory effect on virions.

\section{Results and Discussion}

396 The limited efficacy of the current treatment of WNV infection enhances the need for

397 novel therapies that include substances with innovative viral targets and/or mechanisms

398 of action. So far, only a limited number of plant-derived products are effective against 
399 viruses, which has prompted research into finding new antiviral lead molecules

400 (Lohézic-Le Dévéhat et al. 2002; Schnitzler et al. 2007; Astani et al. 2010; Ocazionez et

401 al. 2010; Elizaquível et al. 2013; Li et al. 2013; Swamy et al. 2016; Tanu and Harper

402 2016).

403 Our study has been performed to analyze the potential capacity of $O$. quixos and $P$.

404 aduncum EOs, collected in the Ecuadorian Amazon, to reduce the WNV replication in 405 infected cells. O. quixos EO was characterized and tested for its antimicrobial, 406 antiplatelet and antithrombotic activity (Naranjo 1981; Sacchetti et al. 2006; Tognolini 407 et al. 2006; Ballabeni et al. 2007; Rolli et al. 2014); from our knowledge no antiviral 408 activities test were performed until now. P. aduncum EO has been investigated by 409 several authors mainly focusing on chemical characterization, antimicrobial, 410 insecticidal, larvicidal and anti-protozoic activities (Guerrini et al. 2009; Ling et al. 411 2009; Oliveira et al. 2013; Bernuci et al. 2016; Monzote et al. 2017; Villamizar et al. 412 2017). In addition, P. aduncum was found active on Poliovirus (Lohézic-Le Dévéhat et 413 al. 2002).

414 In the present work the chemical composition of $O$. quixos and $P$. aduncum EOs was 415 determined by GC-MS and GC-FID. The yield of distillation for O. quixos EO was $4160.13 \pm 0.01 \%(w / v)$, comparable with our previous results (Sacchetti el al. 2006). The 417 main component was represented by 1,8 -cineole $(39.15 \%)$, followed in less amount by $418 \alpha$-terpineol (7.65\%), sabinene (6.46\%), $\alpha$-pinene (6.27\%), p-cymene (6.12\%), E419 caryophyllene (4.73\%), terpinen-4-ol (4.22\%) (Table 1): monoterpenes were therefore 420 the main fraction of EO. This chemical profile did not reflect our previous data 421 (Sacchetti el al. 2006), where E-caryophyllene, cinnamyl acetate and other derivatives 422 were the characteristic molecules. Moreover, methyl cinnamate, a typical 423 phenylpropanoid of floral calyx EO (Bruni et al. 2004), was a minor compound derived 
424 from leaves (1.53\%). The chemical characterization of leaf EO has not been studied

425 extensively in literatur date. However, it can be highlighted tha biodiversity of 426 A hazonian region can induce plant secondary metabolism to biosynthetic pathways 427 characterized by diversified molecule $\$$ at can justify the different chemical profile of 428 EOs derived b same speci@calvenzi et al., 2017).

429 Regarding $P$. aduncum EO, the data were similar to those previously published 430 (Guerrini et al. 2009) wit Denylpropanoi (4) lapiole (48.21\%), trans-ocimene (7.53\%) 431 and E-caryophyllene (4.80\%) as main compounds and small quantitative differences on 432 minor compounds and germacrene D (3.05\%) that was not detected in the past research. 433 The yield was $0.16 \pm 0.01 \%(\mathrm{w} / \mathrm{v})$. P. aduncum $\mathrm{EO}$ have been largely studied in literature 434 in the last two decades and the formation of two chemotypes by different biosynthetic 435 routes has been evidenced. In fact, according to our data, different studies on EOs from 436 leaves of $P$. aduncum leaf OEs, "derived from different localities of Amazonian 437 region", showed that dillapiole, formed by the shikimate pathway, was the main 438 compound with a variability from 31.5\% to 97.3\%, (Cicció and Ballestero 1997, Maia et 439 al. 1998, Fazolin et al. 2007 and De Almeida et al. 2009). In addition, the study of $P$. 440 aduncum cultivation in Western Amazonian region confirmed dillapiole as major 441 component (Silva et al. 2014). If the leaves were instead collected from species in 442 (A) antic Forest, and Northeastern and Southeaster Dazil, terpene compounds such as 443 (E)-nerolidol and linalool were detected as main components (De Oliveira et al. 2006; 444 Debonsi Navickiene et al. 2006; De Almeida et al. 2009). The yield of dillapiole445 chemotype EO in literatur $\bigcirc$ nged from 0.35\% to 4.0\% (Fazolin et al. 2007; Rali et al. 446 2007; De Almeida et al. 2009; Guerrini et al. 2009; Silva et al. 2014), our results instead 447 showed a lower level (0.16\%). 
448 EOs were tested for their cytotoxicity on Vero cells prior to the determination of their

449 inhibitory effect against WNV, by using a neutral re say in which the half maximal

450 cytotoxic concentration $\left(\mathrm{CC}_{50}\right)$ value of each compound was calculated. $P$. aduncum

451 resulted relatively more toxic than $O$. quixos. Indeed, the results illustrated a $\mathrm{CC}_{50}$ value

452 of $163 \mu \mathrm{g} / \mathrm{mL}$ for $P$. aduncum and $840 \mu \mathrm{g} / \mathrm{mL}$ for $O$. quixos. Treated cells with vehicle

453 control, 1\% DMSO, did not show any cytotoxicity against Vero cells (Table 2).

454 In order to evaluate the effect of $O$. quixos and $P$. aduncum on viral replication, Vero

455 cells were infected with WNV at 0.1 m.o.i. p.f.u./cell and exposed to various two-fold@

456 concentrations of EO starting from $2.6 \mu \mathrm{g} / \mathrm{mL}$ for $72 \mathrm{~h}$ post-infection (p.i.).

457 Results are presented in Figure 1 as percentage of cell viability and represent the 458 average of three independent experiments. As shown in the figure, both EOs were able 459 to inhibit viral replication but $O$. quixos was more effective at concentration of 268 and $460 \quad 134.4 \mu \mathrm{g} / \mathrm{mL}$ respect $P$. aduncum that showed a viral inhibition similar for all 461 concentratio $\bigcirc$ he $50 \%$ effective concentration $\left(\mathrm{EC}_{50}\right)$ for $O$. quixos was $372 \mu \mathrm{g} / \mathrm{mL}$ 462 wh selectivity index (SI) of 2.2 (Table 2).

463 In order to better investigate the inhibitory effects of $O$. quixos and $P$. aduncum on

464 WNV, EOs was added at different stages during viral infection. As shown on Figure 2,

465 no relevant differences between the antiviral activities of $\mathrm{OE}$ of $O$. quixos $\mathrm{OE}$ were 466 observed in all conditions studied. The highest percentages of cell viability $(>60 \%)$ 467 were observed when the EO was added to the host cells at the concentrations of 16.8 468 and $33.6 \mu \mathrm{g} / \mathrm{mL}$ prior to the infection. Similar results were obtained when $33.6 \mu \mathrm{g} / \mathrm{mL}$ 469 of EO were added during the adsorption step. Differently, when the EO was added at 470 low concentrations ( 1 and $2.1 \mu \mathrm{g} / \mathrm{mL}$ ) no relevant antiviral activity was observed in any 471 conditions. 
472 Antiviral activity of the $P$. aduncum was most pronounced when the virus was treated

473 before inoculation (Figure 3A) showing a percentage of cell viability of $79 \%$ at the 474 concentrations of $33.6 \mu \mathrm{g} / \mathrm{mL}, 88 \%$ at $16.8 \mu \mathrm{g} / \mathrm{mL}, 87 \%$ and $78 \%$ at 2.1 and $1 \mu \mathrm{g} / \mathrm{mL}$, 475 respectively. When cells were incubated with EO only $1 \mu \mathrm{g} / \mathrm{mL}$ showed protection 476 (68\% of cell viability) while no relevant antiviral activity was shown by the other 477 concentrations (Figure 3(B)). When the EO was added during infection, the results 478 showed an antiviral activity at all the concentrations with a percentage of cell viability 479 of around $68 \%$ at $1 \mu \mathrm{g} / \mathrm{mL}$ (Figure $3(\mathrm{C})$ ).

480 Results of the present paper showe at the antiviral activity of $P$. aduncum EO had 481 manly virucidal activity. In literature there aren't many studies of virucidal effect of

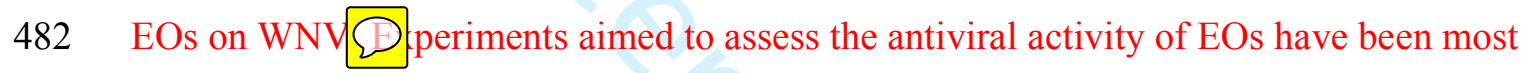
483 frequently conducted on viruses of the herpes group, enveloped viruses (Novak 2011). 484 Schnitzler et al. (2007) demonstrated a virucidal effect of peppermint oil, when herpes 485 simplex virus was mixed with the EO prior to inoculation. The application of tea tree 486 oil, the EO of Melaleuca alternifolia, for the treatment of recurrent herpes labialis has 487 been recently reported (Carson et al. 2001; Schuhmacher et al. 2003). Concerning 488 antiviral activity on others members of the Flaviviridae family, many studies with 489 dengue virus (DENV) have been reported (Garcia et al. 2003; Duschatzky et al. 2005; 490 Raquel Elvira Ocazionez et al 2010; Klawikkan 2011). Thes @ tter data support the 491 hypothesis that $P$. aduncum EO components may directly contribute to the inactivation 492 of viral particles by interfering wit 9 velope or masking viral glycoproteins that are 493 necessary for entering host cells.

494 Accordingly, a virus lacking of envelope, like adenovirus, was not affected by 495 Eucalyptus EO (Cermelli et al. 2008). Therefore our results suggest that O. quixos and 496 P. aduncum could directly inactivate WNV and might interfere with virion envelope 
497 structures or mask viral structures which are necessary for adsorption or entry into host

498 cells.

499 In this study, experiments were also performed to determine the viral inhibitory effect

500 ating the cells with EOs before adsorption. This different approach was important to

501 better investigate on 10 chanisms of antiviral action of the EOs. In our study, O. quixos

502 showed a protection of the cells from viral infection unlik $P$ aduncum.

503 Previous studies with EOs from eucalyptus, tea tree and thyme have shown the direct

504 inactivating action of EOs and their components on virion infectivity (HSV-1), with the

505 exception of 1,8-cineole (Astani et al. 2010). Although 1,8-cineole was the main

506 component of $O$. quixos, our results showed a good antiviral effect of this EO. In

507 particular, Astani et al 1 monstrated that $\alpha$-pinene, $\alpha$-terpineol, terpinen-4-ol and $\mathrm{p}$ -

508 cymene, components detected also in O. quixos EO, revealed a high antiviral activity

509 and could be responsible for inactivation action. These data highlight the need to

510 analyze the efficacy of the single components of $O$. quixos $\mathrm{EO}$ in further studies.

511 For $O$. quixos we observed a good and similar protection from WNV infection ading

512 the EO to the DMEM medium during the intracellular replication period, up to an EO

513 concentration of $16.8 \mu \mathrm{g} / \mathrm{mL}$. These results suggest that $O$. quixos could act directly on

514 WNV virus and might interfere with virion envelope structures or mask viral structures,

515 which are necessary for adsorption or entry into host cells. Thus different mechanisms

516 of antiviral activity of different EOs and compounds seem to be present.

517 P. aduncum didn't resul 1 tective when added to the cells before inoculur this

518 case we might, in some ways, assume that the oil does not act by competing with the

519 virus for binding to the cell, and that part of its activity relies on direct inactivation of 520 the viral particles after virus adsorption. 
521 All together, these results support the potential use of EOs in toto from medicinal plants

522 as agents for the treatment of viral infections. The effectiveness of the EOs from

523 Amazonia against the viruses tested was variable, but their virucidal properties against

524 these viruses suggest the application of this type of natural products as disinfectants or

525 topical medicaments.

526 However, in our research 1 ther investigation is required to better elucidate the active

527 components and their mixture responsible $D$ inhibitory effect on virions.

528 Viral diseases are still a major problem for human health worldwide. Althoug $D$ e

529 intrinsic complexity of natural products, the research tren @ early indicate that plant-

530 based products will be among the most important sources of new drugs in the future

531 (Atanasov et al. 2015).

532

533

534 Acknowledgements

535 This research has been supported by grar $\bigcirc$ om the Universidad Estatal Amazónica, 536 Ecuador, the University of Ferrara, Italy (FAR 2016-Guerrini) and the National 537 Reference Laboratory for Arboviruses, Istituto Superiore di Sanità. The accomplishment 538 of the present article is framed in the activitie the agreement MAE-DNB-CM-20155390027 in force between the Ministry of the Environment of Ecuador and the State 540 University Amazon.

541

\section{Statistical analysis}

543 The experiments were performed in triplicate and were determined by logarithmic

544 regression curves with 95\% confident limits. Relative standard deviations and statistical 


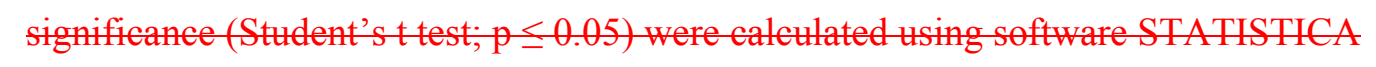

547

\section{$548 \quad$ References}

549 Adams RP. 2007. Identification of Essential Oil Components by Gas 550 Chromatography/Masspectrometry, 4th ed.Carol Stream (IL): Allured Publishing Co

551 Astani A, Reichling J, Schnitzler P. 2010. Comparative Study on the Antiviral Activity of 552 Selected Monoterpenes Derived from Essential Oils. Phytother- Res. (24):673-679.

553 Atanasov AG, Waltenberger B, Pferschy-Wenzig EM, Linder T, Wawrosch C, Uhrin P, 554 Temml V, Wang L, Schwaiger S, Heiss EH. 2015. Discovery and resupply of 555 pharmacologically active plant-derived natural products: A review. Biotechnol- Adv. $556 \quad(33): 1582-1614$.

557 Ballabeni V, Tognolini M, Bertoni S, Bruni R, Guerrini A, Moreno Rueda G. Barocelli E. 558 2007. Antiplatelet and antithrombotic activities of essential oil from wild Ocotea quixos 559 (1Lam.) kKosterm (Ltauraceae) calices from amazonian Ecuador. Pharmacol- Res. (55):23$560 \quad 30$.

561 Bernuci ZK, Iwanaga CC, Fernandez-Andrade CMM, Brusco Lorenzetti F, Caio Torres562 Santos E, dos Santos Faiões V, Gonçalves JE, do Amaral W, Deschamps C, de Lima Scodro 563 R, Fressatti Cardoso R, Vanessa PietrowskiBaldin V, Garcia Cortez DA. 2016. Evaluation 564 of Chemical Composition and Antileishmanial and Antituberculosis Activities of Essential $565 \quad$ Oils of Piper Species. Molecules. (21):1698.

566 Bhalla Y, Gupta VK, Jaitak V. 2013. Anticancer activity of essential oil: A review. J- Sci$567 \quad$ Food Agric. (93):3643-3653. 
568 Bruni R, Medici A, Andreotti E, Fantin C, Muzzoli M, Dehesa M, Romagnoli C, Sacchetti

569 G. 2004. Chemical composition and biological activities of ishpingo essential oil, a 570 traditional ecuadorian spice from Ocotea quixos (Lam.) Kosterm. (Lauraceae) flower $571 \quad$ calices. Food Chem. (85):415-421.

572 Carson CF, Ashton L, Dry L, Smith DW, Riley TV. 2001. Melaleuca alternifolia (tea tree) 573 oil gel (6\%) for the treatment of recurrent herpes labialis. J Antimicrob Chemother. (48): $574 \quad 450-451$.

575 Cicció JF, Ballestero CM. 1997. Constituyentes volátiles de las hojas y espigas de Piper 576 aduncum (Piperaceae) de Costa Rica. Rev Biol Trop. 45(2):783-790.

577 Cermelli C, Fabio A, Fabio G, Quaglio P. 2008. Effect of Eucalyptus Essential Oil on 578 Respiratory Bacteria and Viruses. CurrMicrobiol. 56(1):89-92.

579 David S, Abraham AM. 2016. Epidemiological and clinical aspects on West Nile virus, a 580 globally emerging pathogen. Infect Dis (Lond). 48(8):571-86.

581 De Almeida RRP, Souto RNP, Bastos CN, Da Silva MHL, Maia JGS. 2009. Chemical 582 variation in Piper aduncum and biological properties of its dillapiole-rich essential oil. 583 ChemBiodivers. 6(9):1427-1434.

584 Debonsi Navickiene HM, Morandim ADA, Alécio AC, Regasini LO, Bergamo DCB, 585 Telascrea M, Cavalheiro AJ, Lopes MN, Bolzani VDS, Furlan M, Marques MOM, Young 586 MCM, Kato MJ. 2006. Composition and antifungal activity of essential oils from Piper 587 aduncum, Piper arboreum and Piper tuberculatum. Quím. Nova. 29(3):467-470.

588 De Oliveira JCS, Dias IJM, Da Camara CAG. 2006. Volatile Constituents of the Leaf Oils 589 of Piper aduncum L. from Different Regions of Pernambuco (Northeast of Brazil). J Essent $590 \quad$ Oil ResESSENT OIL RES. 18(5):557-559. 
1

2

3

4

5

6

7

8

9

10

591 Durant-Archibold AA, Santana AI, Gupta PM. 2018. Ethnomedical uses and 592 pharmacological activities of most prevalent species of genus Piper in Panama: A review. $593 \quad$ Journal of Ethnopharmacol. (217): 63-82

594 Elizaquível P, Azizkhani M, Aznar R, Sánchez G. 2013. The effect of essential oils on 595 norovirus surrogates. Food Control. (32):275-278.

596 Fazolin M, Estrela JLV, Catani V, Alécio MR, de Lima MS. 2007. Insecticidal properties of 597 essential oils of Piper hispidinervum C. DC.; Piper aduncum L. and Tanaeciumnocturnum 598 (Barb. Rodr.) Bur. \& K. Shum against Tenebrio molitor L. Ciênc- agrotec. 31 (1):113-120

599 Fortuna C, Remoli ME, Di Luca M, Severini F, Toma L, Benedetti E, Bucci P, Montarsi F, 600 Minelli G, Boccolini D, Romi R, Ciufolini MG. 2015. Experimental studies on comparison 601 of the vector competence of four Italian Culexpipiens populations for West Nile 602 virus.Parasit Vectors. (8):463.

603 Friedman J, Bolotin D, Rios M, Mendosa P, Cohen Y, Balick M.J. 1993. A novel method 604 for identification and domestication of indigenous useful plants in Amazonian Ecuador. $605 \quad$ New crops. 167-174.

606 García, CC, Talarico L, Almeida N, Colombres S, Duschatzky C and Damonte EB. 2003. 607 Virucidal activity of essential oils from aromatic plants of San Luis, Argentina. Phytother $608 \quad$ Res. 17:1073-1075.

609 Gubler DJ. 2007. The continuing spread of West Nile virus in the western hemisphere. Clin$610 \quad$ InfectDis. 45(8):1039-1046.

611 Guerrini A, Rossi D, Grandini A, Scalvenzi L, Noriega Rivera PF, Andreotti E, Tacchini M, 612 Spagnoletti A, Poppi I, Maietti S. 2014. Biological and chemo-diverse characterization of 613 Amazonian (Ecuador) Citruspetitgrains. J Appl Bot Food Qual. (87):108-116. 
614 Guerrini A, Sacchetti G, Rossi D, Paganetto G, Muzzoli M, Andreotti E, Tognolini M, 615 Maldonado ME, Bruni R. 2009. Bioactivities of Piper aduncum L. and Piper obliquum Ruiz 616 \&Pavon (Piperaceae) essential oils from Eastern Ecuador. Environ Toxicol Pharmacol. $617 \quad 27(1): 39-48$.

618 Li D, Baert L, Uyttendaele M. 2013. Inactivation of food-borne viruses using natural 619 biochemical substances. Food Microbiol. (35):1-9.

620 Ling A I, Sulaiman S, Othman H. 2009. Evaluation of Piper aduncum Linn. Essential Oil 621 (Fam:Piperaceae) against Periplanetaamericana (L.). Iranian J Arthropod-Borne Dis. 3(2): $622 \quad 1-6$

623 Lohézic-Le Dévéhat F, Bakhtiar A, Bézivin C, Amoros M, Boustie J. 2002. Antiviral and 624 cytotoxicactivities of some Indonesianplants. Fitoterapia. (73):400-405.

625 Magurano F, Remoli ME, Baggieri M, Fortuna C, Marchi A, Fiorentini C, Bucci P, 626 Benedetti E, Ciufolini MG, Rizzo C, Piga S, Salcuni P, Rezza G, Nicoletti L. 2012. 627 Circulation of West Nile virus lineage 1 and 2 during an outbreak in Italy. ClinMicrobiol $628 \quad$ Infect. (12) 545-547.

629 Maia, JGS, Zohhbi MDGB, Andrade EHA, Santos AS, Da Silva MHL, Luz AIR, Bastos 630 CN. 1998. Constituents of the essential oil of Piper aduncum L. growing wild in the 631 Amazon region. Flavour Fragr- J. 13(4):269-272.

632 Mamood SN, Hidayatulfathi O, Budin SB, Ahmad Rohi G, Zulfakar MH. 2017. The 633 formulation of the essential oil of Piper aduncum Linnaeus (Piperales: Piperaceae) increases 634 its efficacy as an insect repellent. Bull Entomol Res. (1):49-57.

635 Mittermeier RA, Mittermeier CG, Gil PR. 1999. Megadiversity: Earth's biologically 636 wealthiest nations. Chelonian Conserv. Biol. (3):537-537. 
1

2

3

4

5

6

7

8

637 Monzote L, Scull R, Cos P, Setzer WN. 2017. Essential Oil from Piper aduncum: Chemical

638 Analysis, Antimicrobial Assessment, and Literature Review. Medicines. 4(49).

639 Naranjo P. 1981. Ocotea quixos, American cinnamon. J. Ethnopharmacol. (4):233 - 236.

640 Newman DJ, Cragg GM. 2007. Natural products as sources of new drugs over the last 25 641 years. J- Nat- Prod. (70):461-477.

642 Nowak A. 2011. The inhibitory effect of essential oil on HSV-1 and HSV-2 virus. Post $643 \quad$ Fitoter. (4):243-247.

644 Ocazionez RE, Meneses R, Torres FA, Stashenko E. 2010. Virucidal activity of Colombian 645 Lippia essential oils on dengue virus replication in vitro. Mem Inst Oswaldo Cruz, Rio de $646 \quad$ Janeiro. 105(3):304-309.

647 Oliveira GL, Cardoso SK, Lara Júnior CR, Vieira TM, Guimães EF,FiguereidoLS, Martins 648 ER, Moreira DL, Kaplan MAC. 2013. Chemical study and larvicidal activity against 649 Aedesaegypti of essential oil of Piper aduncum L. (Piperaceae). An AcadBrasCienc. 85(4).

650 Pietrantoni A, Fortuna C, Remoli ME, Ciufolini MG, Superti F. 2015. Bovine lactoferrin 651 inhibits Toscana virus infection by binding to heparan sulphate. Viruses. Jan 29;7(2):480652495.

653 Rali T, Wossa SW, Leach DN, Waterman PG. 2007. Volatile chemical constituents of Piper 654 aduncum L and Piper gibbilimbum C. DC (Piperaceae) from Papua New Guinea.Molecules. $655 \quad 12(3): 389-394$.

656 Rolli E, Marieschi M, Maietti S, Sacchetti G, Bruni R. 2014. Comparative phytotoxicity of 65725 essential oils on pre- and post-emergence development of solanum lycopersicum 1.: A 658 multivariate approach. Ind Crops Prod. (60):280-290. 
659 Sacchetti G, Guerrini A, Noriega P, Bianchi A, Bruni R. 2006. Essential oil of wild 660 Ocoteaquixos (Lam.) Kosterm. (Lauraceae) leaves from amazonian Ecuador. FlavourFragr661 J. (21):674-676.

662 Saxena V, Bolling BG, Wang T. 2017. West Nile Virus. Clin Lab Med. Jun;37(2):243-252.

663 Scalvenzi L, Grandini A, Spagnoletti A, Tacchini M, Neill D, Ballesteros JL, Sacchetti G, 664 S. Guerrini A. 2017. Myrciasplendens (Sw.) DC. (syn. M. fallax (Rich.) DC.) (Myrtaceace) 665 essential oil from Amazonian Ecuador: A chemical characterization and bioactive profile. 666 Molecules. (22)(7):E1163.

667 Schnitzler P, Koch C, Reichling J. 2007. Susceptibility of Drug-Resistant Clinical Herpes 668 Simplex Virus Type 1 Strains to Essential Oils of Ginger, Thyme, Hyssop, and 669 Sandalwood. Antimicrob- Agents Chemother. May51(5):1859-1862.

670 Schuhmacher J, Reichling J, P. Schnitzler P. 2003. Virucidal effect of peppermint oil on the 671 enveloped viruses herpes simplex virus type 1 and type 2 in vitro. Phytomedicine. (10)(6672 7):504-510.

673 Sierra R, Campos F, Chamberlin J. 2002. Assessing biodiversity conservation priorities: 674 Ecosystem risk and representativeness in continental Ecuador. Landsc Urban Plan. Int. J. 675 Geogr. Inf. Sci. (59(2)):95-110.

676 Silva AL, Chaves FCM, Lameira RC, Bizzo HR. 2014. Yield and composition of the 677 essential oil from Piper aduncum L., cultivated in Manaus, AM, regarding plant density and 678 cutting period. Rev- bBras: pPlantas mMed. 15(4)(SUPPLSupp11):670-674.

679 Swamy MK, Akhtar MS, Sinniah UR. 2016. Antimicrobial Properties of Plant Essential 680 Oils against Human Pathogens and Their Mode of Action: An Updated Review. Evid681 Based Complement- Alternat- Med. Article ID 3012462:, 21 682 pageshttp://dx.doi.org/10.1155/2016/3012462 
683 Tanu B, Harpreet K. 2016. Benefits of essential oil. J Chem Pharm Res. 8(6):143-149.

684 Tognolini M, Barocelli E, Ballabeni V, Bruni R, Bianchi A, Chiavarini M, Impicciatore M. 685 2006. Comparative screening of plant essential oils: Phenylpropanoid moiety as basic core 686 for antiplatelet activity. Life Sciences. (78):1419-1432.

687 Vázquez-Calvo Á, Jiménez de Oya N, Martín-Acebes MA, Garcia-Moruno E, Saiz JC. 688 2017. Antiviral Properties of the Natural Polyphenols Delphinidin and Epigallocatechin 689 Gallate against the Flaviviruses West Nile Virus, Zika Virus, and Dengue Virus. Front $690 \quad$ Microbiol. 8:1314.

691 Villamizar LH, Cardoso MDG, de Andrade J, Teixeira ML, Soares MJ. 2017.Linalool, a 692 Piper aduncum essential oil component, has selective activity against Trypanosoma cruzi 693 trypomastigote forms at $4^{\circ} \mathrm{C}$. Mem Inst Oswaldo Cruz, Rio de Janeiro. 112(2):131-139. 
Figure 1. Antiviral activity of $O$. quixos $(\bullet$ ) and P. aduncum ( $\square$ ) against WNV during intracellular virus replication. Results are presented as mea 20 three independent experiments \pm SD $(\mathrm{p}<0.05)$

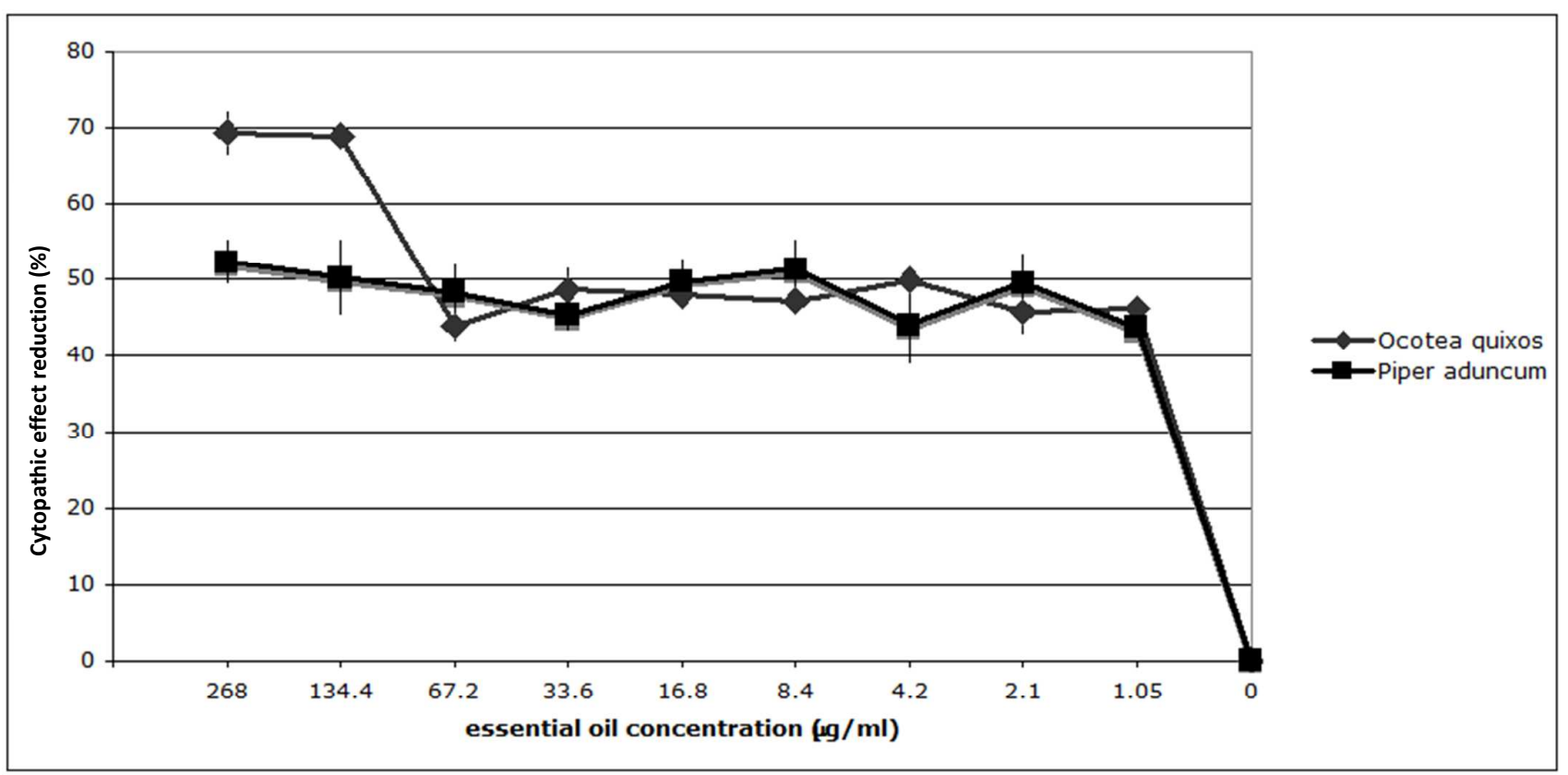


Figure 2. Antiviral activity of $O$. quixos against WNV at 0.1 m.o.i.p.f.u./cell (A) after incubation of QD us with different concentratid $\mathrm{EO} 1 \mathrm{~h}$ at $37^{\circ} \mathrm{C}$ before infection ; (B) after pre-treatment of cells with drugs before viral infection $1 \mathrm{~h}$ at $37^{\circ} \mathrm{C}(\mathbf{C})$ after treatment with different concentratioQD: EO during infection. $\mathrm{CC}=$ cell control; $\mathrm{CV}=$ virus control
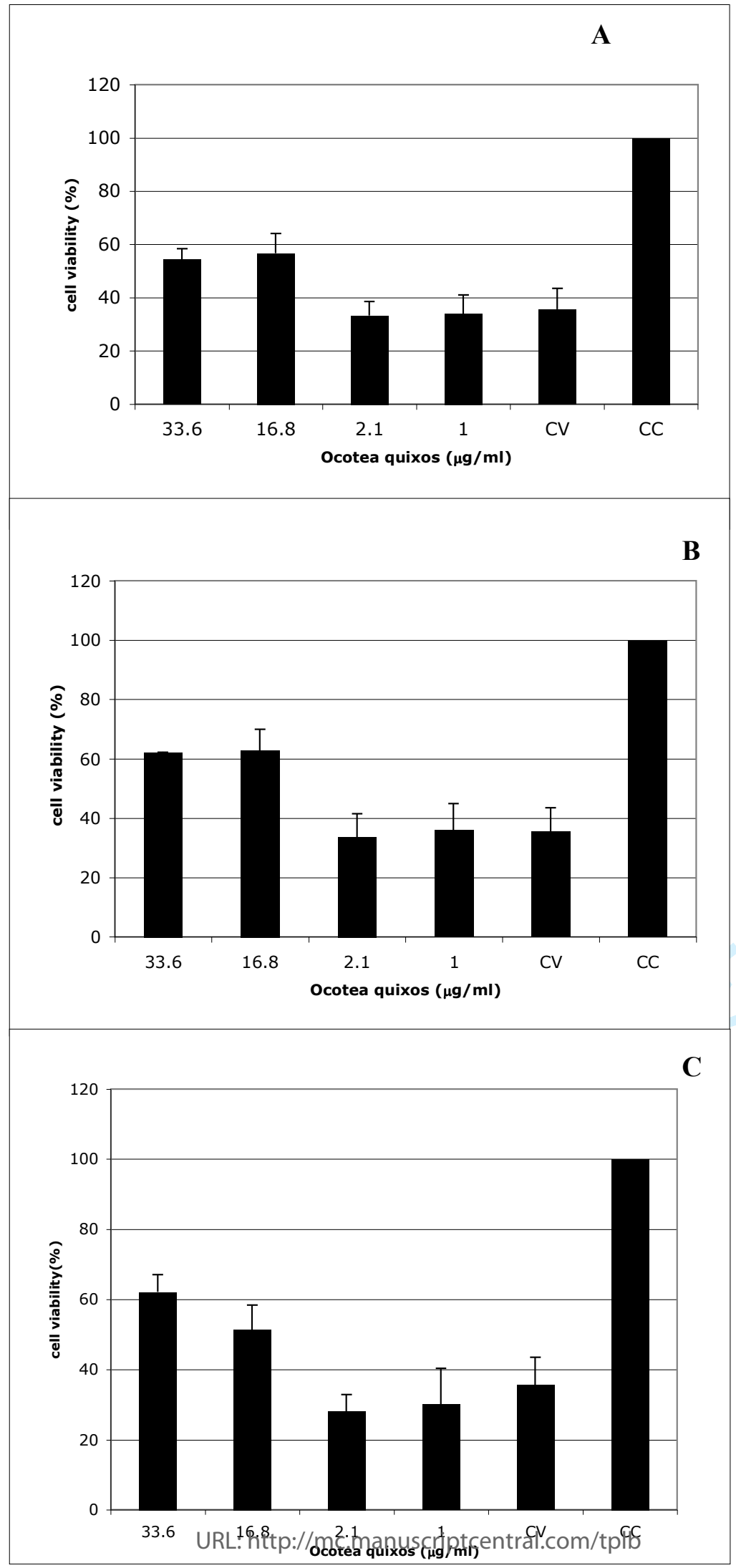
Figure 3. Antiviral activity of $P$. aduncum against WNV at 0.1 m.o.i. p.f.u./cell (A) after incubation of virus with different concentratid $\mathrm{EO} 1 \mathrm{~h}$ at $37^{\circ} \mathrm{C}$ before infection; (B) after pre-treatment of cells with drugs before viral infection $1 \mathrm{~h}$ at $37^{\circ} \mathrm{C}(\mathbf{C})$ after treatment with different concentratio of EO during infection. $\mathrm{CC}=$ cell control; $\mathrm{CV}=$ virus control
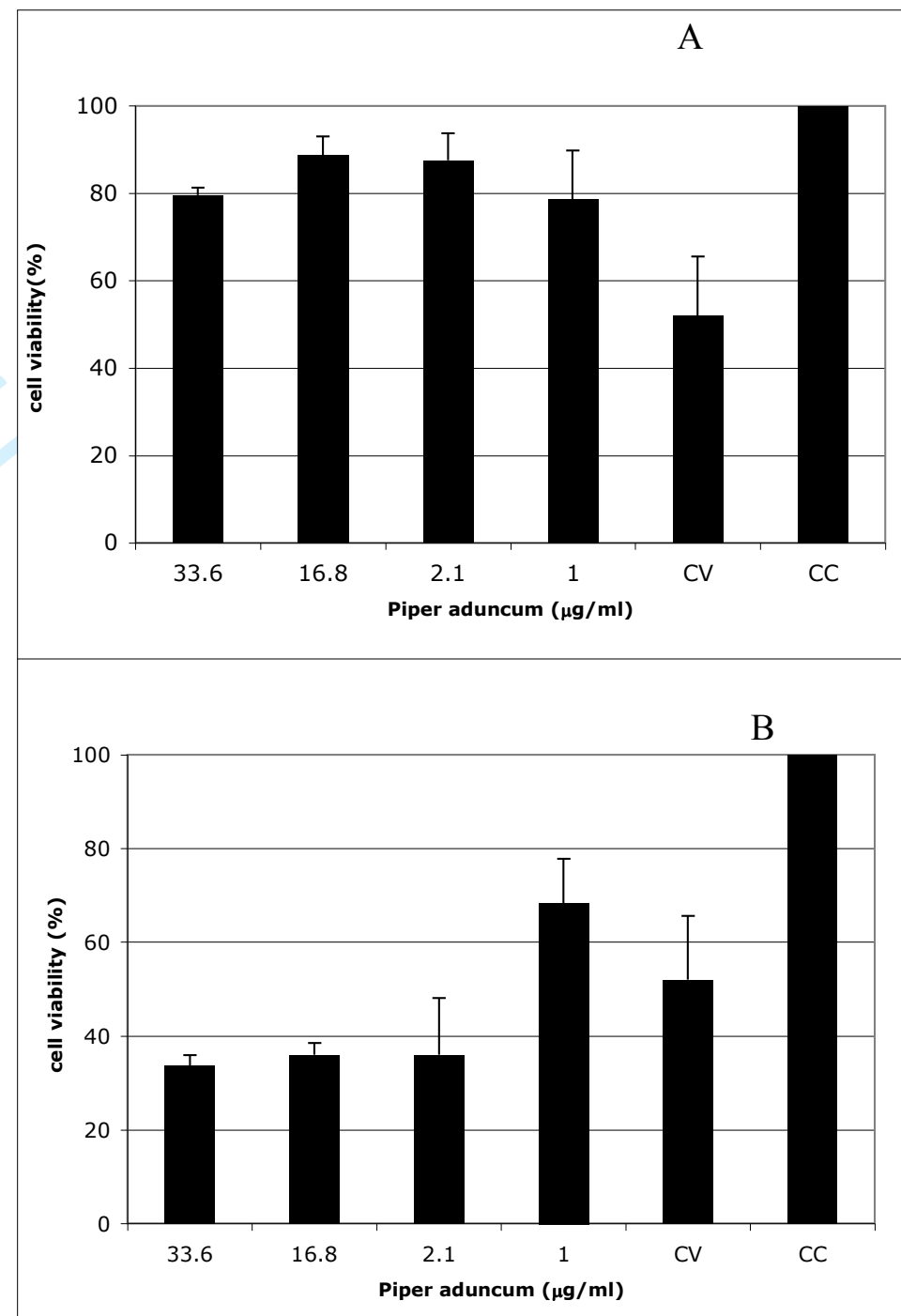
Table 1. Chemical composition of $O$. quixos and P. aduncum EOs

\begin{tabular}{|c|c|c|c|c|c|}
\hline No. & Component $^{1}$ & $\begin{array}{l}\text { O. quixos } \\
(\text { Area } \%)^{21}\end{array}$ & $\begin{array}{l}\text { P. aduncum } \\
(\text { Area\% } \%)^{21}\end{array}$ & $R I \exp ^{3 z}$ & $\begin{array}{l}\text { RI lit } \\
\text { lett }^{3}\end{array}$ \\
\hline 1 & $\alpha$-thujene & $1.50 \pm 0.09$ & $0.23 \pm 0.02$ & 922 & 924 \\
\hline 2 & $\alpha$-pinene & $6.27 \pm 0.47$ & $1.63 \pm 0.14$ & 929 & 932 \\
\hline 3 & camphene & $0.16 \pm 0.02$ & - & 944 & 946 \\
\hline 4 & sabinene & $\mathbf{6 . 4 6} \pm 0.39$ & - & 967 & 969 \\
\hline 5 & $\beta$-pinene & $3.45 \pm 0.21$ & $0.99 \pm 0.08$ & 973 & 974 \\
\hline 6 & myrcene & $0.83 \pm 0.06$ & $0.42 \pm 0.03$ & 987 & 988 \\
\hline 7 & $\alpha$-phellandrene & $0.31 \pm 0.03$ & $0.78 \pm 0.05$ & 1005 & 1002 \\
\hline 8 & p-mentha-1(7),8-diene & $0.48 \pm 0.04$ & $0.16 \pm 0.01$ & 1006 & 1005 \\
\hline 9 & $\alpha$-terpinene & $1.73 \pm 0.11$ & $0.63 \pm 0.04$ & 1014 & 1014 \\
\hline 10 & p-cymene & $\mathbf{6 . 1 2} \pm 0.42$ & $1.48 \pm 0.13$ & 1021 & 1020 \\
\hline 11 & o-cymene & - & $1.21 \pm 0.10$ & 1025 & 1023 \\
\hline 12 & limonene & $1.84 \pm 0.11$ & $1.10 \pm 0.11$ & 1026 & 1024 \\
\hline 13 & 1,8-cineole & $\mathbf{3 9 . 1 5} \pm 2.32$ & 2 & 1028 & 1026 \\
\hline 14 & cis-ocimene & - & $3.33 \pm 0.27$ & 1032 & 1032 \\
\hline 15 & trans-ocimene & - & $\mathbf{7 . 5 3} \pm 0.48$ & 1043 & 1044 \\
\hline 16 & $\gamma$-terpinene & $3.05 \pm 0.18$ & $1.99 \pm 0.16$ & 1053 & 1054 \\
\hline 17 & p-mentha-2,4(8)-diene & $0.35 \pm 0.02$ & $1.27 \pm 0.10$ & 1082 & 1085 \\
\hline 18 & $\delta$-terpineol & $0.47 \pm 0.04$ & - & 1167 & 1162 \\
\hline 19 & terpinen-4-ol & $4.22 \pm 0.25$ & $1.63 \pm 0.12$ & 1176 & 1174 \\
\hline 20 & $\alpha$-terpineol & $\mathbf{7 . 6 5} \pm 0.51$ & - & 1193 & 1186 \\
\hline 21 & piperitone & - & $3.78 \pm 0.25$ & 1250 & 1249 \\
\hline 22 & $\delta$-elemene & - & $0.10 \pm 0.01$ & 1337 & 1335 \\
\hline
\end{tabular}




\begin{tabular}{|c|c|c|c|c|c|}
\hline 23 & $\alpha$-cubebene & $0.40 \pm 0.03$ & $0.18 \pm 0.02$ & 1351 & 1345 \\
\hline 24 & cyclosativene & - & $0.36 \pm 0.03$ & 1369 & 1370 \\
\hline 25 & $\alpha$-ylangene & - & $0.18 \pm 0.01$ & 1371 & 1373 \\
\hline 26 & $\alpha$-copaene & $1.44 \pm 0.08$ & $1.23 \pm 0.11$ & 1376 & 1374 \\
\hline 27 & $\beta$-cubebene & - & $0.11 \pm 0.01$ & 1387 & 1387 \\
\hline 28 & $\beta$-elemene & - & $0.58 \pm 0.03$ & 1388 & 1389 \\
\hline 29 & trans-methylcinnamate & $1.53 \pm 0.06$ & - & 1389 & 1388 \\
\hline 30 & $\alpha$-gurjunene & - & $0.50 \pm 0.02$ & 1398 & 1409 \\
\hline 31 & E-caryophyllene & $\mathbf{4 . 7 3} \pm 0.33$ & $\mathbf{4 . 8 0} \pm 0.35$ & 1410 & 1416 \\
\hline 32 & $\alpha$-santalene & - & $0.10 \pm 0.01$ & 1414 & 1417 \\
\hline 33 & $\beta$-copaene & - & $0.31 \pm 0.02$ & 1424 & 1430 \\
\hline 34 & $\gamma$-elemene & - & $0.18 \pm 0.01$ & 1427 & 1434 \\
\hline 35 & aromadendrene & - & $0.29 \pm 0.02$ & 1432 & 1439 \\
\hline 36 & $\alpha$-humulene & $2.96 \pm 0.21$ & $1.74 \pm 0.16$ & 1451 & 1452 \\
\hline 37 & $\begin{array}{c}\text { trans-cadina-1(6),4- } \\
\text { diene }\end{array}$ & - & $0.17 \pm 0.02$ & 1470 & 1475 \\
\hline 38 & $\gamma$-muurolene & - & $0.54 \pm 0.05$ & 1473 & 1478 \\
\hline 39 & germacrene D & - & $3.05 \pm 0.29$ & 1477 & 1484 \\
\hline 40 & $\beta$-chamigrene & $0.13 \pm 0.02$ & - & 1480 & 1480 \\
\hline 41 & $\beta$-selinene & $2.00 \pm 0.18$ & $0.32 \pm 0.02$ & 1484 & 1489 \\
\hline 42 & $\gamma$-amorphene & - & $0.28 \pm 0.02$ & 1487 & 1495 \\
\hline 43 & viridifilorene & - & $0.52 \pm 0.04$ & 1491 & 1496 \\
\hline 44 & bicyclogermacrene & $0.79 \pm 0.06$ & - & 1491 & 1500 \\
\hline 45 & $\alpha$-muurolene & - & $0.33 \pm 0.03$ & 1495 & 1500 \\
\hline 46 & n-pentadecane & - & $0.24 \pm 0.01$ & 1500 & 1500 \\
\hline
\end{tabular}


$$
47
$$

47 (E,E)- $\alpha$-farnesene

$0.53 \pm 0.05$

1504

1506

$48 \quad \gamma$-cadinene

$0.44 \pm 0.04$

1509

1513

$49 \quad \delta$-amorphene

$0.43 \pm 0.04$

$1.39 \pm 0.12$

1516

1511

$50 \quad$ myristicin

$0.64 \pm 0.05$

1524

1517

$51 \quad$ trans- $\gamma$-bisabolene

$0.26 \pm 0.02$

1526

1531

trans-cadina-1(2),4-

52

diene

53

$\alpha$-cadinene

$-$

-

526

1531

54 germacrene B

55 spathulenol

$0.50 \pm 0.04$

$0.16 \pm 0.01$

1531

1533

\begin{tabular}{cccccc}
56 & caryophyllene oxide & $0.44 \pm 0.03$ & $0.48 \pm 0.03$ & 1581 & $\mathbf{1 5 8 2}$ \\
57 & viridiflorol & - & $1.13 \pm 0.11$ & 1593 & $\mathbf{1 5 9 2}$ \\
58 & humulene epoxide II & $0.19 \pm 0.02$ & $0.27 \pm 0.02$ & 1609 & $\mathbf{1 6 0 8}$ \\
59 & dillapiole & - & $\mathbf{4 8 . 2 1} \pm 2.65$ & 1622 & $\mathbf{1 6 2 2}$ \\
\hline & Total identified & 99.42 & 98.77 &
\end{tabular}

${ }^{1}$ Components are listed in order of elution and their nomenclature is in accordance of the NIST (National Institute of Standards and Technology) library; ${ }^{2}$ Relative peak areas \pm SEM (standard error media), calculated by GC-FID; ${ }^{3}$ RI exp: linear retention indices calculated on a Varian VF5ms column; ${ }^{4} \mathrm{RI}$ lit: linear retention indices (Adams et al. 2007). 
Table 2. $\mathrm{CC}_{50}=50 \%$ cytotoxic concentration $(\mu \mathrm{g} / \mathrm{mL}) ; \mathrm{EC}_{50}=50 \%$ effective concentration $(\mu \mathrm{g} / \mathrm{mL}) ; \mathrm{SI} 50=$ selectivity index $\left(\mathrm{CC}_{50} / \mathrm{EC}_{50} \Omega\right.$

\begin{tabular}{|c|c|c|c|}
\hline & CC $_{\mathbf{5 0}}$ & $\mathbf{E C}_{\mathbf{5 0}}$ & SI \\
\hline O. quixos & $840 \mu \mathrm{g} / \mathrm{mL}$ & $372 \mu \mathrm{g} / \mathrm{mL}$ & 2.2 \\
\hline $\boldsymbol{P}$. aduncum & $163 \mu \mathrm{g} / \mathrm{mL}$ & $163 \mu \mathrm{g} / \mathrm{mL}$ & 1 \\
\hline
\end{tabular}

